\title{
ISSN $2303-3223$
}
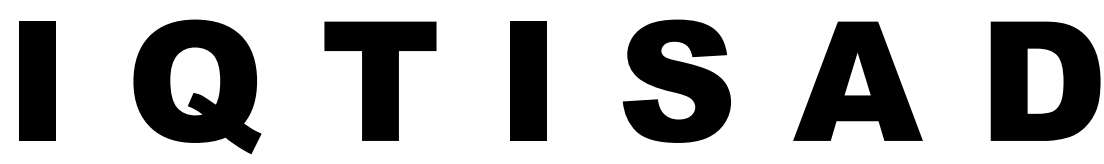

Reconstruction of Justice and Welfare for Indonesia

\section{Penanggung Jawab}

Nur Cholid (Dekan Fakultas Agama Islam)

\author{
Redaktur Ahli \\ Imam Yahya, (UIN WALISONGO) \\ M. Nasrudin (IAIN Metro Lampung) \\ Ahmad Rofiq (UIN WALISONGO) \\ Al Haq Al Kamal (Universitas Ali Maksum Yogyakarta) \\ Nanang Nurcholis (UNWAHAS)
}

\author{
Pimpinan Redaksi \\ Linda Indiyarti Putri \\ Sekretaris Redaksi \\ Imam Khoirul Ulumudin
}
Redaktur pelaksana
Ulya Himawati
A. Saiful Aziz
Ubbadul Adzkiya'

\section{Dewan Redaksi}

Iman Fadhilah

Ali Romdhoni

Tedi Kholiludin

Ghufron Hamzah

\section{Pusat Data dan Dokumen}

Hamid Sakti Wibowo

\author{
Desain Grafis
}

Aris Abdul Ghoni

Publikasi

M. Sholih in

\section{Alamat}

HES - FAI Universitas Wahid Hasyim Semarang

Jln. Menoreh Tengah X / 22 Sampangan, Semarang, 50236, Telp / Faks ( 024 ) 8505681

e-mail ; iqtisad@unwahas.ac.id 


\section{PENGANTAR REDAKSI}

Bismillāhir-rahmānir-rahĩm.

Alhamdulillah, atas ijin Allah SWT, jurnal Iqtisad Volume 5 No. 1 Tahun 2018 dapat hadir di lingkungan Universitas Wahid Hasyim Semarang. Kini Jurnal Iqtisad memiliki nuansa baru sebagai lanjutan dari edisi sebelumnya. Jurnal Iqtisad diterbitkan oleh Pusat Kajian dan Pengembangan Ilmu-ilmu Keislaman (PKPI2) Fakultas Agama Islam Universitas Wahid Hasyim Semarang yang senantiasa terus menyajikan hasil-hasil penelitian dan pemikiran terbarukan dari para peneliti, dosen, maupun praktisi di bidang hukum dan ekonomi Islam.

Hasil penelitian yang terangkum dalam jurnal sudah melalui tahapan yang panjang agar hasil yang disajikan dapat dinikmati dengan baik oleh para pembaca. Kami menyakini benar bahwa penelitian ini merupakan bentuk kepedulian dari peneliti dalam membangun kualitas penelitian di Indonesia.

Semoga sajian kami memberikan manfaat bagi para pembaca.

Wassalamualaikum Wr Wb

Linda Indiyarti Putri

Pemimpin Redaksi 


\section{Q T I S A D}

Reconstruction of Justice and Welfare for Indonesia

\section{Daftar Isi}

Pengantar Redaksi :

Daftar Isi

iii

PERALIHAN AGAMA DAN AKIBAT HUKUMNYA DALAM KONTEKS PERKAWINAN DITINJAU DARI PERSPEKTIF HUKUM POSITIF DI INDONESIA

Etika Rahmawati

PERLINDUNGAN HUKUM TERHADAP HAK IMUNITAS ADVOKAT DALAM PENEGAKAN HUKUM DI INDONESIA

Kamal Arif

PRAKTIK JUAL BELI SAHAM SYARI'AH PERSPEKTIF HUKUM ISLAM

Ahmad Faqih

ANALISIS HUKUM ISLAM TERHADAP PRAKTIK JUAL BELI IKAN DI PELABUHAN PERIKANAN NUSANTARA PEKALONGAN

Nurul Istiqomah

PENGARUH LOKASI, PELAYANAN, DAN PROSEDUR PENCAIRAN PEMBIAYAAN TERHADAP KEPUTUSAN ANGGOTA KOPERASI MENGAMBIL PEMBIAYAAN

Al Haq Kamal \& Septi Wulandari: 


\title{
ANALISIS HUKUM ISLAM TERHADAP PRAKTIK JUAL BELI IKAN DI PELABUHAN PERIKANAN NUSANTARA PEKALONGAN
}

\author{
Nurul Istiqomah \\ Alumni FAI Universitas Wahid Hasyim \\ nurulistiqomah922@gmail.com
}

\begin{abstract}
Abstrak
Jual beli diperbolehkan dalam Islam tetapi belum tentu semua jual beli yang berada dimasyarakat benar dan baik. Perlunya evaluasi terhadap pelaksanaan jual beli lelang ikan di TPI (Tempat Pelelangan Ikan) apakah sudah sesuai dengan prinsip-prinsip syariah yang sesuai dengan hukum jual beli Islam. Yang menjadi permasalahan ini adalah bagaimana pelaksanaan praktik jual beli ikan di TPI (Tempat Pelelangan Ikan), apa bentuk usaha yang dilakukan dan apa faktor pendukung dan penghambat dalam jual beli pelelangan ikan.

Penelitian ini bertujuan untuk menganalisis secara kritis praktik jual beli ikan antara pihak TPI (Tempat Pelelangan Ikan) dengan pembeli tanpa kehadiran pemilik (nelayan) Studi Kasus di Pelabuhan Perikanan Nusantara Pekalongan yang kemudian dianalisis dengan perspektif hukum Islam serta faktor pendukung dan penghambatnya. Hasil penelitian ini diharapkan dapat dipergunakan dalam upaya pencapaian tujuan tempat pelelangan ikan.

Penelitian ini merupakan penelitian kualitatif, dengan mengambil tempat di TPI (Tempat Pelelangan Ikan) (studi kasus Pelabuhan Perikanan Nusantara Pekalongan). Pengumpulan data dilakukan dengan mengadakan observasi, wawancara mendalam dan dokumentasi. Subjek penelitiannya yaitu pemilik barang (nelayan), pembeli (bakul) dan pihak TPI (Tempat Pelelangan Ikan) di Pelabuhan Perikanan Nusantara Pekalongan. Analisis data dilakukan secara deskriptif dengan menerapkan pola berfikir induktif. Analisis ini lebih merupakan pembentukan abstraksi berdasarkan bagian-bagian yang telah dikumpulkan.

Hasil penelitian menujukkan pihak penjual dan pembeli sama sama hadir dalam pelelangan. Dalam praktiknya jual beli lelang ikan di TPI (Tempat Pelelangan Ikan) Pelabuhan Perikanan Nusantara Pekalongan perlu adanya pengawasan ekstern dan intern.
\end{abstract}

Kata Kunci: Jual Beli Lelang Ikan, Hukum Islam, dan Pembelian Tanpa Kehadiran Pemilik (nelayan).

Jurnal IQTISAD - Volume 5, Nomor 1, Juni 2018

ISSN: 2303-3223 


\begin{abstract}
Trading is allowed in Islam but not all trading is in good order. Evaluation is needed in fish auction trading in Fish Auction Place (TPI, is it already accordance with the principles of sharia and Islamic trading law. The problem is how the implementation of fish trading in TPI, what form of business done and what factors supporting and inhibiting the fish auction trading.

This study aims to analyze critically the practice of fish trading between TPI and buyer without the presence of owner (fisherman). Case Study at the Fishery Port of Nusantara Pekalongan then analyzed with the perspective of Islamic law and its supporting and inhibiting factors. The results of this study are expected to be used in achieving the goals of fish auction.

This research is a qualitative research, taking place in TPI (case study of Fishery Port of Pekalongan). Data collection is done by conducting observation, in-depth interview and documentation. Research subjects are the owner of fish (fishermen), buyers (bakul) and TPI at Fishery Port of Nusantara Pekalongan. Data analysis was done descriptively by applying inductive thinking pattern. This analysis is more of an abstraction formation based on parts that have been collected.

The results showed that the sellers and buyers are present together in auction. In practice the fish auction trading at TPI Fishery Port of Nusantara Pekalongan need external and internal supervision
\end{abstract}

Keyword: fish auction trading, Islamic law, purchasing without owner (fishermen)

\title{
A. PENDAHULUAN
}

Jual beli merupakan akad yang umum digunakan oleh masyarakat karena dalam setiap pemenuhan kebutuhannya, masyarakat tidak bisa berpaling untuk meninggalkan akad ini. Terdapat berbagai pendapat mengenai definisi jual beli, bahwa inti jual beli adalah suatu perjanjian tukar menukar benda atau barang yang mempunyai nilai secara suka rela di antara kedua belah pihak, yang satu menerima benda-benda dan pihak yang lain menerimanya

Jurnal IQTISAD - Volume 5, Nomor 1, Juni 2018

ISSN: 2303-3223 
sesuai dengan perjanjian atau ketentuan yang telah dibenarkan oleh syara' dan disepakati. ${ }^{1}$

Jual beli yang muncul yang berkembang salah satunya adalah jual beli dengan sistem lelang. Yang dimaksud dengan Pelelangan Ikan adalah penjualan ikan yang dilakukan dihadapan umum dengan cara penawaran tertinggi sebagai pemenang. ${ }^{2}$ Jadi pelelangan ikan merupakan salah satu sistem jual beli dengan menjual ikan secara terbuka dengan mencari tawaran yang lebih tinggi.

Pelaksanaan pelelangan ikan yang terjadi di TPI (Tempat Pelelangan Ikan) Pelabuhan Perikanan Nusantara Pekalongan dapat digambarkan sebagai berikut : Persiapan lelang adalah hal pertama yang dilakukan sebelum transaksi pelelangan dimulai. Pada tahap persiapan ini kapal yang merapat di dermaga dengan membawa hasil tangkapan laut dan segera di bawa ke TPI, kemudian diadakan pembongkaran oleh ABK (Anak Buah Kapal) Ikan diletakkan dalam keranjang (basket fish) yang disediakan oleh petugas dan berat ikan ditentukan oleh juru tawar. Juru tawar menawarkan ikan kepada bakul dengan penawaran yang tinggi dan menunjukkan keadaan ikan yang digelar di balai lelang. Penawaran harga yang semakin menurun atau meningkat sampai akhirnya terjadi kesepakatan harga dengan pembeli (bakul). Bakul menyatakan sepakat/setuju dengan menggunakan isyarat tangan.

${ }^{1}$ Hendi Suhendi, Fiqh Muamalat, cet. ke-6, Jakarta : Rajawali Pers, 2010, h. 68-69.

2 Peraturan Daerah Kota Pekalongan Nomor 11 Tahun 2015 Tentang Pengelolaan Tempat Pelelangan Ikan, pasal 1, ayat 13.

Jurnal IQTISAD - Volume 5, Nomor 1, Juni 2018

ISSN: 2303-3223 
Namun terkadang dalam pelaksanaan pelelangan, pada saat kesepakatan penentuan harga yang terjadi di TPI Pelabuhan Perikanan Nusantara Pekalongan terjadi ketidakhadiran pemilik barang lelang (nelayan), yang memungkinkan terjadinya kecurangan dalam penentuan harga. Seperti halnya harga tidak sesuai dengan kondisi ikan (ngiyom), jenis ikan, dan lain sebagainya.

Padahal dalam proses pelelangan tersebut merupakan tawar menawar harga antara penjual (nelayan) dengan pembeli (bakul), dan TPI lah sebagai tempat bertemu antara keduanya, sampai pada kestabilan harga yang disepakati antara pemilik (nelayan) dan pembeli (bakul).

Atas dasar pemikiran tersebut penyusun merasa tertarik untuk mengetahui lebih jauh lagi tentang pelaksanaan jual beli ikan antara pihak TPI (Tempat Pelelangan Ikan) dengan pembeli tanpa kehadiran pemilik (nelayan) (studi kasus di Pelabuhan Perikanan Nusantara Pekalongan). Apakah dalam praktik tersebut dikatakan jual beli seperti pada umumnya atau upah mengupah (ijarah al-a'mal), atau wakalah, maka untuk memaparkan permasalahan, diperlukan penelitian serta pembahasan yang lebih mendalam.

\section{B. METODE PENELITIAN}

Dalam hal ini ada beberapa langkah-langkah yang akan peneliti gunakan dalam menyelesaikan penelitian ini adalah Penelitian Lapangan (Field Research). Data yang dimaksud di sini adalah data yang berkaitan dengan praktik jual beli ikan yang

Jurnal IQTISAD - Volume 5, Nomor 1, Juni 2018

ISSN: 2303-3223 
dilakukan antara pihak TPI (Tempat Pelelangan Ikan) dengan pembeli tanpa kehadiran pemilik (nelayan) di Pelabuhan Perikanan Nusantara Pekalongan.

Pendekatan penelitian yang digunakan dalam penelitian ini adalah pendekatan normatif, yaitu dengan mendekati sebuah masalah untuk melihat apakah sesuatu itu baik atau buruk, sah atau batal, sesuai atau tidak sesuai menurut norma yang berlaku. Disamping itu untuk menyederhanakan pembenarannya atau penemuan hukum atas masalah yang diangkat dengan tolak ukur persesuaian dengan nas-nas dan ketentuan hukum Islam.

Untuk mendapatkan subjek penelitian ini adalah dengan menggunakan teknik sampling, yaitu penelitian dengan tidak menyelidiki semua objek, semua gejala, semua kejadian atau peristiwa, melainkan hanya sebagian saja dari obyek gejala atau kejadian yang dimaksud. ${ }^{3}$ Adapun subyek penelitian dalam penelitian ini, adalah pemilik barang (nelayan), pembeli (bakul) dan pihak TPI (Tempat Pelelangan Ikan) di Pelabuhan Perikanan Nusantara Pekalongan.

Adapun Obyek penelitian dalam tulisan ini meliputi: (1) Ketidakhadiran pemilik barang (nelayan) dalam pelelangan, (2) akad atau kontrak yang dilakukan oleh nelayan dengan pihak TPI (Tempat Pelelangan Ikan), (3) pandangan hukum Islam mengenai jenis pelelangan seperti ini.

${ }^{3}$ Sutrisno Hadi, Metode Research, Yogyakarta: Fakultas Psikologi UGM, 1983, h. 70.

Jurnal IQTISAD - Volume 5, Nomor 1, Juni 2018

ISSN: 2303-3223 


\section{PEMBAHASAN}

1. Analisis Praktik Jual Beli Ikan Antara Pihak TPI (Tempat Pelelangan Ikan) Dengan Pembeli Tanpa Kehadiran Pemilik (Nelayan) (Studi Kasus Di Pelabuhan Perikanan Nusantara Pekalongan)

Jual beli sistem lelang merupakan suatu sarana yang sangat tepat untuk menampung para pembeli untuk mendapatkan barang yang telah diinginkannya. Sehingga benar-benar apa yang telah diinginkannya telah tercapai. Jual beli dengan sistem lelang juga harus mempunyai sistem menajemen yang professional dalam menjalankan tugas dan perannya di masyarakat. Sehingga pelelangan yang terjadi merupakan pelelangan yang berbasis keadilan, yaitu harga yang digunakan harus adil. Dengan adanya berbagai pertimbangan yang sangat dijunjung tinggi tidak melarang dalam melakukan usaha untuk mencari kekayaan sebanyak-banyaknya dan dengan cara seperti apa selama cara yang dilakukan masih berada dalam garis yang dihalalkan. Oleh karena itu tentunya tidak sematamata hanya mengikuti aturan belaka yang hanya menjadi dasar, tetapi merupakan suatu aturan yang berfungsi menjaga dari adanya manipulasi atau kecurangan-kecurangan dalam menjalankan bisnis dengan cara lelang.

Dalam bab sebelumnya telah penulis paparkan tentang praktik jual beli lelang ikan di Pelabuhan Perikanan Nusantara Pekalongan. Dari hasil observasi serta wawancara dengan nelayan (penjual), bakul (pembeli) serta pihak TPI (Tempat Pelelangan Ikan) penulis mendapatkan gambaran yang cukup jelas bagaimana pelaksanaan jual beli lelang ikan di Pelabuhan Perikanan Nusantara Pekalongan.

Jurnal IQTISAD - Volume 5, Nomor 1, Juni 2018

ISSN: 2303-3223 
Kegiatan pelelangan ikan di Pelabuhan Perikanan Nusantara Pekalongan dilakukan sejak 1920. Pelaksanaan jual beli lelang ikan di TPI Pekalongan tidak jauh berbeda dengan jual beli lelang ikan pada umumnya, seperti biasanya dilakukan pelelangan ikan di TPI (Tempat Pelelangan Ikan), ada juru tawar dan kemudian ada penjual (nelayan) dan pembeli (bakul). Terkait hal ini, peneliti melakukan wawancara dengan pihak TPI, penjual dan pembeli dalam pelaksanaan jual beli lelang ini.

Dari hasil observasi yang peneliti lakukan di Tempat Pelelangan Ikan Pekalongan, praktik jual beli lelang ikan sedikit berbeda dengan praktik jual beli lelang ikan pada umumnya. Bahwa jual beli lelang ikan ini sangat rentan dengan spekulasi karena berat ikan perbasket ditentukan oleh juru tawar sehingga adanya ketidak akuratan juru tawar menentukan berat perbasket ikan, dan terkadang kondisi ikan (ngiyom) yang tidak sesuai dengan harga dan lain sebagainya. Maka akibatnya dapat terjadi saling menyalahkan, ataupun merasa dirugikan antara pihak penjual (nelayan) maupun pembeli (bakul).

Dalam hal menentukan harga awal pasar pelelangan yakni ditentukan oleh harga ikan hari kemarin sesuai dengan jenis ikan yang dilelangkan. Atau pun dengan penentuan harga awal pasar pelelangan sesuai dengan daerah Jakarta apabila harga ikan tidak stabil. Tetapi dalam pelaksanaanya lebih sering digunakan adalah patokan harga ikan hari kemarin saat terakhir dilakukan pelelangan di Pelabuhan Perikanan Nusantara Pekalongan.

Unsur kehati-hatian harus ditekankan dalam praktik jual beli lelang ikan ini. Pada saat kapal merapat di dermaga TPI kemudian

Jurnal IQTISAD - Volume 5, Nomor 1, Juni 2018

ISSN: 2303-3223 
mengambil surat ijin bongkar, nomor urut lelang dan keranjang/basket ikan. Setelah semua selesai kemudian dilakukan pembongkaran yang dimulai pada malam hari. Saat proses pengelompokkan ikan per jenis harus sangat diperhatikan per mutu / kualitas, dan besar / kecilnya agar nantinya tidak terjadi protes dari pembeli (bakul) tentang ikan yang tidak sesuai dengan mutu. Kemudian setelah selesai baru dilakukan penimbangan lalu dimasukkan ke dalam keranjang/basket fish untuk dilakukan pelelangan.

Setelah ikan dimasukkan kedalam keranjang, maka pembeli dapat melihat atau mengecek kondisi ikan yang akan mereka jadikan sasaran pembelian. Hampir setiap peserta memegang catatan di tangannya, selain untuk menulis jumlah bungkus ikan yang sudah dibeli dan harga yang disepakati, juga untuk mencatat jumlah ikan yang dibeli oleh pesaingnya. Peserta lelang berpengalaman tentu memiliki strategi untuk mendapatkan harga ikan terbaik. Sementara nelayan berharap mendapat harga tertinggi.

Untuk menentukan berat perbasket ikan haruslah dilakukan proses penimbangan, meskipun dalam hal ini berat perbasket sudah ditentukan oleh juru tawar, tetapi untuk keakuratan berat ikan perbasket maka perlu adanya proses penimbangan oleh juru timbang jadi ikan memang benar-benar sudah melalui tahap penimbangan yang akurat.

Pengawasan kegiatan penimbangan harus dilakukan oleh kepala teknik lelang dengan melakukan inspeksi langsung ke lapangan dan adanya penindakan secara tegas berupa teguran dan sangsi terhadap petugas yang bekerja tidak baik. Unsur kehati-hatian

Jurnal IQTISAD - Volume 5, Nomor 1, Juni 2018

ISSN: 2303-3223 
dan kecermatan dilakukan agar terhindar dari unsur spekulasi dan agar terhindar dari kerugian baik dari pihak penjual (nelayan) maupun pembeli (bakul).

Dalam proses pelelangan di TPI Pelabuhan Perikanan Nusantara Pekalongan pihak antara penjual (nelayan) dan pembeli (bakul) sama-sama hadir dalam satu majelis/tempat meskipun pihak pemilik kapal selaku penjual tidak langsung menanganinya tetapi dengan memberikan kepercayaan kepada ABK yang sudah di tunjuk pemilik kapal (pemilik ikan) untuk mewakilinya dalam pelaksanaan pelelangan.

Dapat disimpulkan bahwa dalam kegiatan pelelangan antara pihak TPI (tempat pelelangan ikan) dengan pembeli tetap adanya kehadiran pemilik (nelayan). Jadi tidak ada hal yang menyimpang dengan hukum Islam, maka dalam persyaratan ini diperbolehkan. Dengan pengawasan terhadap semua kegiatan TPI secara intern harus dilakukan oleh kepala TPI dan masing-masing kepala bagian.

Pengawasan dilakukan secara langsung melalui inspeksi setiap hari yang dilakukan baik oleh pihak TPI maupun kepala bagiannya. Pengawasan ekstern juga harus dilakukan oleh instansi atau lembaga terkait seperti PPNP, Dinas Perikanan Provinsi Jawa Tengah atau yang lainnya.

Hasil penelitian memberikan informasi bahwa pelelangan ikan di Tempat Pelelangan Ikan Pelabuhan Perikanan Nusantara Pekalongan bahwa sistem pelelangan sudah dilakukan dengan professional dengan sumber fasilitas yang baik seperti dermaga, pabrik es, toilet, air bersih, para juragan kapal dan masjid. Dengan juga ditunjang oleh kegiatan administrasi yang rapih dan tertib antara

Jurnal IQTISAD - Volume 5, Nomor 1, Juni 2018

ISSN: 2303-3223 
masing-masing juru yang bekerja sesuai dengan tugasnya masingmasing.

Hal tersebut membuktikan bahwa pelelangan ikan di Pelabuhan Perikanan Nusantara Pekalongan sudah dikelola secara optimal. Dengan pelaksanaan jual beli seperti dengan adanya juru tawar yang memimpin pelelangan dengan cepat, tertib, tegas dan sopan, kemudian ada penjual (nelayan) dan pembeli (bakul).

Kekurangan dan kelebihan pelelangan ikan di Tempat Pelelangan Ikan Pelabuhan Perikanan Nusantara Pekalongan adanya praktik yang masih sangat rentan dengan spekulasi karena berat ikan perbasket ditentukan oleh juru tawar sehingga adanya ketidak akuratan juru tawar menentukan berat perbasket ikan, dan terkadang kondisi ikan (ngiyom) yang tidak sesuai dengan harga dan lain sebagainya. Maka akibatnya dapat terjadi saling menyalahkan, ataupun merasa dirugikan antara pihak penjual (nelayan) maupun pembeli (bakul). Dikelolanya potensi sumber daya perikanan dan kelautan secara optimal oleh Pelabuhan Perikanan Nusantara sehingga mampu mewujudkan kesejahteraan nelayan dan masyarakat perikanan bukan hanya di daerah Pekalongan itu sendiri tetapi untuk seluruh nelayan dan masyarakat di Indonesia.

2. Analisis Hukum Islam Terhadap Praktik Jual Beli Ikan Antara Pihak TPI (Tempat Pelelangan Ikan) Dengan Pembeli Tanpa Kehadiran Pemilik (Nelayan) (Studi Kasus Di Pelabuhan Perikanan Nusantara Pekalongan)

Dalam menjalankan muamalah, manusia tidak terikat dan bebas melakukan apapun selama tidak ada nash-nash yang melarang

Jurnal IQTISAD - Volume 5, Nomor 1, Juni 2018

ISSN: 2303-3223 
dan mencegah perbuatan yang mereka lakukan, demikian halnya dengan masalah jual beli.

Praktik jual beli ikan dengan sistem lelang sudah terjadi sejak lama di Pekalongan. Pada bab ini penulis akan menganalisis dalam pandangan hukum Islam terhadap praktik jual beli ikan antara pihak TPI (Tempat Pelelangan Ikan) dengan pembeli tanpa kehadiran pemilik (nelayan) (Studi Kasus Di Pelabuhan Perikanan Nusantara Pekalongan).

Dilihat dari keabsahan jual beli, penulis menganalisa pelaksanaan jual beli ikan dengan cara lelang di TPI Pekalongan, dengan melihat dari sisi rukun dan syarat syahnya jual beli menurut Hukum Islam.

1. Shighat (Ijab dan Qabul)

Adapun syarat-syarat ijab dan qabul adalah sebagai berikut:

a. Dalam satu majelis atau tempat

b. Baligh dan berakal

c. Tidak ada perkataan yang memisahkan akad keduanya

d. Jelas dan lugas. ${ }^{4}$

Berdasarkan hasil penelitian yang penulis lakukan bahwa dalam pelaksanaannya jual beli lelang ikan ini adalah jual beli yang telah memenuhi persyaratan shighat. Dalam hal ini sebagaimana disebut dalam bab III yang menerangkan adanya proses transaksi jual beli.

${ }^{4}$ Nasrun Haroen, MA. Fiqh Muamalah, Jakarta: Gaya Media Pratama, 2007, h. 117 .

Jurnal IQTISAD - Volume 5, Nomor 1, Juni 2018

ISSN: 2303-3223 
Dalam jual beli lelang ikan ini adanya khiyar majlis adalah tempat yang dijadikan berlangsungnya transaksi jual beli. Kedua pihak melakukan jual beli memiliki hak pilih antara mau meneruskan atau membatalkan jual beli selama masih berada dalam majlis. Dalilnya bisa dilihat dari apa yang disabdakan oleh Rasulullah SAW.

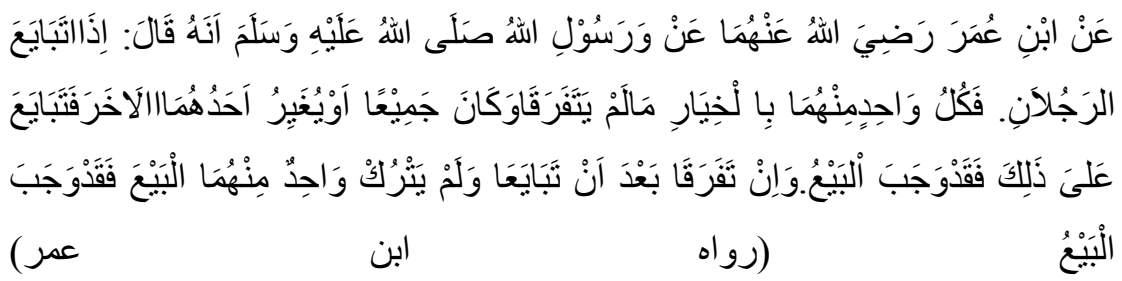

Artinya: “ Diriwayatkan dari Ibnu Umar r.a., dari Rasulullah SAW. Beliau bersabda "Apabila dua orang mengadakan jual beli, masing-masing mempunyai hak khiyar (boleh memilih antara melangsungkan jual beli atau membatalkannya). Atau salah seorang dari keduanya saling mengadakan perjanjian hak pilih, lalu dia menetapkan jual beli dengan perjanjian itu, maka jadilah jual beli itu dengan cara perjanjian tersebut. Jika sesudah berjual beli itu dengan cara perjanjian tersebut. Jika seseorang berjual beli mereka berpisah dan salah seorang diantara mereka tidak meninggalkan barang yang dijual belikan, jadilah jual beli itu”.

Ibnul Qayyim al-Jauziyyah berpendapat, “Ketetapan Allah tentang disyari'atkannya khiyar majlis dalam jual beli mengandung hikmah dan maslahat yang dalam bagi kedua belah pihak yang melakukan transaksi. Selain itu bertujuan agar keridhaan kedua pihak dapat dicapai dengan sempurna", 
sebagaimana yang telah dipesankan Allah dalam al-Qur'an surat an-Nisa ayat 29.

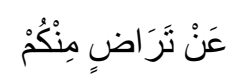

Artinya: "Dengan suka sama suka di antara kamu."

Jika keduanya sepakat untuk tidak memiliki khiyar dalam transaksi jual beli tersebut, atau salah satu darinya tidak menghendaki khiyar, maka gugurlah khiyar tersebut. Dan jual beli tetap menjadi hak kedua belah pihak atau menjadi hak orang yang menggagalkan khiyar dalam akad. Sebab khiyar pada dasarnya adalah hak yang dimiliki oleh pihak yang mengadakan akad. Ia akan jatuh bersamaan dengan jatuhnya khiyar tersebut.

Tidak diperbolehkannya salah satu dari kedua pihak yang mengadakan transaksi untuk meninggalkan saudaranya dengan maksud untuk menggugurkan hak khiyarnya. Hal ini tidak diperbolehkan berdasarkan hadits yang diriwayatkan oleh Amru Ibnu Syu'aib yang disebutkan di dalamnya:

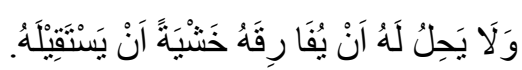

Artinya: "Dan tidak diperbolehkan baginya untuk meninggalkan saudaranya, karena takut jual beli dibatalkan."

2. Al-muta'aqidain (pihak yang berakad)

Sebagaimana telah dijelaskan di bab II, yang menjadi syarat dalam melakukan jual beli adalah baligh berakal, saling meridhai, tidak mubazir (pemboros). ${ }^{5}$ Sementara itu jual beli ikan

${ }^{5}$ Hendi Suhendi, Fiqh Muamalat, cet. ke-6, Jakarta: Rajawali Pers, 2010, h. 74. 
di TPI Pekalongan pihak antara penjual (nelayan) dan pembeli (bakul) sama-sama hadir dalam satu majlis/tempat meskipun pihak pemilik kapal selaku penjual tidak langsung menanganinya tetapi dengan memberikan kepercayaan kepada ABK yang sudah di tunjuk pemilik kapal (pemilik ikan) untuk mewakilinya dalam pelaksanaan pelelangan.

Menurut peneliti jual beli tersebut sah dilakukan dengan karena pihak pemilik kapal (pemilik ikan) telah mempercayakan kepada salah satu ABK (anak buah kapal) untuk melaksanakan pelelangan ikan miliknya.

Seperti telah dijelaskan dalam bab II tentang syarat sah jual beli terkait dengan pelaksanaan jual beli yaitu jual beli baru boleh dilaksanakan apabila yang berakad mempunyai kekuasaan untuk melakukan jual beli, misalnya barang itu milik sendiri (barang yang dijual itu bukan milik orang lain atau hak orang lain terkait dengan barang itu). Akad jual beli tidak boleh dilaksanakan apabila orang yang melakukan akad tidak memiliki kekuasaan untuk melaksanakan akad. Misalnya seseorang bertindak mewakili orang lain dalam jual beli. Dalam hal ini, pihak wakil harus mendapatkan persetujuan terdahulu dari orang yang mewakilinya. Apabila orang yang mewakilinya setuju, maka barulah hukum jual beli itu dianggap sah. Jual beli seperti ini, dalam fiqh Islam disebut bai' al-fudhuli. 
Pendapat ulama Malikiyah dalam masalah jual beli alfudhuli, adalah sah, baik dalam menjual maupun membeli dengan syarat diizinkan oleh orang yang diwakilinya. ${ }^{6}$

3. Ma'qud Alaih (objek akad)

Bahwa syarat-syarat yang terkait dengan barang yang diperjualbelikan adalah barang tersebut merupakan kepunyaan si penjual, kepunyaan yang diwakilinya atau yang mengusahakan, memberikan manfaat menurut syar'a yakni tidak boleh menjual sesuatu yang termasuk hal menyia-nyiakan (memboroskan), Tidak boleh ditaklikan atau digantungkan dengan hal-hal yang lain yakni dikaitkan atau digantungkan kepada hal-hal lain, tidak dibatasi dengan waktu dan diketahui atau dapat dilihat.

Berdasarkan penelitian yang dilakukan penulis dilapangan bahwa ikan yang diperjualbelikan harus diperhatikan proses pengelompokkan ikan per mutu / kualitas, dan besar / kecilnya agar tidak terjadi protes dari pembeli (bakul) tentang ikan yang tidak sesuai dengan mutu, setelah selesai baru dilakukan penimbangan kemudian dimasukkan kedalam keranjang/basket fish untuk dilakukan pelelangan.

Dalam hal ini bertujuan agar tidak terjadi unsur kezaliman dan spekulasi antara penjual dan pembeli baik sebelum maupun sesudah dilakukannya proses pelelangan.

Rasulullah saw bersabda:

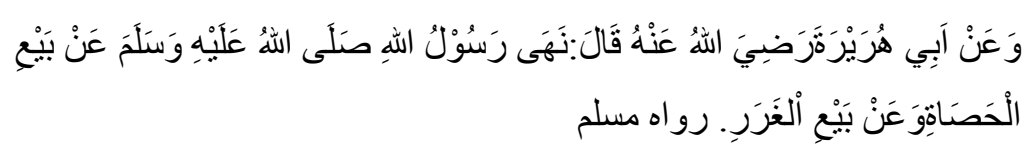

${ }^{6}$ Nasrun Haroen, MA, Op. Cit., h. 121-122. 
Artinya: Dan dari Abu Hurairah Radhiyallahu Anhu, dia berkata, "Rasulullah Shallallahu Alaihi wa Sallam melarang jual beli dengan cara melempar batu dan jual beli gharar (spekulasi)." (HR. Muslim). ${ }^{7}$

Penjelasan hadits diatas adalah, Jual beli dengan cara melempar batu. Ulama berbeda pendapat dalam menafsirkan makna Jual beli dengan cara melempar batu. Ada yang mengatakan, bahwa bentuknya adalah si penjual berkata, "Lemparlah batu ini, di manapun batu ini jatuh mengenai baju, maka ia menjadi milikmu dengan harga satu dirham." Ada juga yang mengatakan, "Si penjual menjual tanah sejauh lemparan batu si pembeli. Atau ada yang mengatakan, "Ia dengan cara menggenggam batu lalu berkata, "Saya akan mendapati barang yang dijual sesuai jumlah batu yang keluar dari genggaman saya." Atau seseorang menjual barang dagangan dengan cara menggenggam batu di tangannya seraya mengatakan bahwa saya akan dapat harga sesuai jumlah batu yang keluar dari genggaman tangan saya yang setiap batu dihargai satu dirham. Pendapat lain, yakni dengan cara salah satu dari penjual ataupun pembeli menggenggam batu di tangannya kemudian mengatakan bahwa kapanpun batu itu jatuh dari genggamannya maka wajib transaksi jual beli dilakukan. Pendapat lain, yakni dengan menghadang sejumlah kambing lalu mengambil batu sambil mengatakan,

${ }^{7}$ Ibnu Hajar al-Asqalani, Bulughul Maram dan Dalil-dalil Hukum: Bab Syaratsyarat Jual Beli dan Hal-hal yang Tidak Boleh Diperjualbelikan, Hadits No. 816. Jakarta: Gema Insani, 2013. h. 336.

Jurnal IQTISAD - Volume 5, Nomor 1, Juni 2018

ISSN: 2303-3223 
kambing mana saja yang terkena lemparan batu akan menjadi milikmu dengan harga sekian dirham. Semua bentuk transaksi jual beli tersebut mengandung spekulasi kecurangan karena harga atau jenis barangnya fiktif tidak jelas. Kata gharar mencakup itu semua, ia disebutkan dalam bentuk tunggal karena keberadaannya sebagai transaksi yang biasa dilakukan orang-orang jahiliyah yang akhirnya dilarang Nabi Shallallahu Alaihi wa Sallam. Dan mengaitkan jual beli dengan batu karena memang mereka menggunakannya dalam transaksi jual beli.

Jual beli gharar, yaitu spekulasi yang berkonsekuensi adanya ketidakrelaan setelah transaksi jual beli benar-benar terjadi. Pada akhirnya hal ini masuk kriteria memakan harta orang lain dengan cara yang batil. Dan terealisasi dalam bentuk, Ketidakmampuan untuk menyerahkan barang kepada si pembeli seperti menjual budak yang kabur dan kuda yang lari, Keberadaan barang yang fiktif dan tidak jelas, Si penjual tidak secara penuh memiliki barang yang dijualnya seperti ikan di dalam air yang banyak atau bentuk transaksi jual beli lain yang serupa.

Maka dari uraian diatas dapat disimpulkan bahwa jual beli lelang ikan ini harus memenuhi rukun dan syarat jual beli menurut Hukum Islam, yang pertama, shighat (Ijab dan qabul) dimana jual beli lelang ikan ini terjadi khiyar majlis yakni hak untuk meneruskan atau membatalkan jual beli tetapi jika keduanya sepakat untuk tidak memiliki khiyar maka gugurlah khiyar tersebut. Kedua, al-Mutaaqidain (pihak yang berakad) jual beli lelang ikan ini dilakukan antara persetujuan mewakilkan pemilik kapal (pemilik ikan) yang dalam hukum Islam jual beli

Jurnal IQTISAD - Volume 5, Nomor 1, Juni 2018

ISSN: 2303-3223 
dianggap sah dan disebut bai' al-fudhuli. Ketiga, Ma'qud Alaih (objek akad) syarat yang terkait dengan barang yang diperjualbelikan, dengan memperhatikan dari awal sampai akhir proses pembongkaran kapal supaya barang dalam hal ini berbentuk ikan layak untuk diperjualbelikan. Dengan tidak mengandung unsur spekulasi antara penjual dan pembeli yang dapat mengakibatkan saling menyalahkan, ataupun merasa dirugikan antara pihak penjual (nelayan) maupun pembeli (bakul) baik sebelum maupun sesudah dilakukannya proses pelelangan dan tidak mengandung unsur gharar yang masuk dalam kriteria memakan harta orang lain dengan cara yang batil sehingga dalam pelaksanaannya dapat sesuai dengan syariat hukum Islam.

\section{Analisis Faktor Pendukung Dan Penghambat Pelaksanaan} Praktik Jual Beli Ikan Di TPI (Tempat Pelelangan Ikan)

\section{Pelabuhan Perikanan Nusantara Pekalongan}

Di samping adanya faktor pendukung jual beli ikan juga ada faktor yang menghambat dalam pelaksanaan jual beli ikan di Tempat Pelelangan Ikan. Adapun faktor yang menghambat antara lain sebagai berikut:

a. Perijinan Kapal Sulit

Faktor perijinan kapal menjadi sesuatu yang sangat penting, karena menyangkut hal awal yang akan dilakukan sebelum melakukan kegiatan mencari ikan. Faktor perijinan akan mempengaruhi jumlah kapal yang akan berlayar dan nantinya akan mendarat di dermaga PPN Pekalongan untuk melakukan kegiatan pelelangan ikan di Tempat Pelelangan Ikan PPN

Jurnal IQTISAD - Volume 5, Nomor 1, Juni 2018

ISSN: 2303-3223 
Pekalongan. Maka diharapkan adanya tindakan edukasi ataupun bimbingan secara langsung akan proses pembuatan surat-surat perijinan kapal.

b. Muara Sungai Dangkal

Salah satu masalah yang menghambat di PPN Pekalongan adalah muara sungai yang dangkal, setiap terjadinya musim kemarau. Selanjutnya dibutuhkan penanganan untuk menyelesaikan masalah tersebut, agar proses mobilitas ikan tidak terganggu hanya karena terjadinya musim kemarau.

c. Faktor Cuaca (musim)

Cuaca (musim) menjadi hal utama dalam menentukan keberhasilan pencarian ikan. Dari tahun ketahun Indonesia mengalami cuaca yang sangat ekstream sehingga sangat mempengaruhi musim ikan yang akan berakibat pada banyak atau sedikitnya jumlah tangkapan. Maka para nelayan sebelum mencari ikan harus melihat perkiraan cuaca agar tidak membayakan dirinya.

d. Sering Terjadinya Ketidakpuasan Pembeli (bakul)

Dalam kegiatan pelelangan ikan di TPI PPN Pekalongan tidak terlepas dari terjadinya kesalahpahaman ataupun ketidakpuasan di antara salah satu pihak yang melakukan pelelangan. Seperti salah satu kekecewaan pembeli (bakul) terhadap ikan yang telah dibeli pada proses pelelangan, penyebabnya adalah perbedaan ukuran ikan antara yang berada dibawah dan diatas keranjang/basket fish. Maka akibatnya pembeli (bakul) meminta pengurangan harga atas ikan yang sudah mereka beli tersebut. Atau bahkan pembeli (bakul)

Jurnal IQTISAD - Volume 5, Nomor 1, Juni 2018

ISSN: 2303-3223 
mengembalikan ikan yang sudah mereka beli kepada penjual (pemilik ikan) maka akibatnya dilakukanlah pelelangan ulang ikan tersebut. Tetapi apabila terjadi persetujuan atau kebijaksanaan dari pemilik ikan untuk mengurangi harga ikan yang telah dibeli oleh bakul, maka proses jual beli tersebut selesai atau tidak perlu dilakukan adanya lelang ulang.

Dalam hal ini pihak TPI sangat berpengaruh terhadap semua permasalahan yang terjadi baik dalam proses pelelangan ataupun setelah kegiatan pelelangan agar semua permasalahan dapat diselesaikan dengan baik.

Pihak TPI (Tempat Pelelangan Ikan) dalam menanggapi faktor-faktor tersebut salah satunya adalah dengan menyelesaikan secara langsung dengan pihak-pihak yang bermasalah, seperti contohnya apabila terjadi masalah dalam berlangsungnya kegiatan pelelangan antara penjual (nelayan) dengan pembeli (bakul) maka pihak pengurus TPI akan memberikan solusi baik itu mediasi pihak yang bermasalah hingga menemukan titik temu permasalahan. Sehingga dengan adanya usaha tersebut berbagai faktor penghambat yang ada dapat diminimalisir agar proses pelelangan di Pelabuhan Perikanan Nusantara Pekalongan dapat mencapai tujuan yang diharapkan. ${ }^{8}$

Sedangkan untuk faktor pendukung jual beli ikan di Tempat Pelelangan Ikan, yaitu :

a. Sumber Fasilitas yang Baik dan Lengkap

${ }^{8}$ Abdul Rozak, Kepala Urusan Administrasi, wawancara, tanggal 1 November 2016, jam 10:00-10:25 WIB, Tempat Pelelangan Ikan Pelabuhan Perikanan Nusantara Pekalongan.

Jurnal IQTISAD - Volume 5, Nomor 1, Juni 2018

ISSN: 2303-3223 
Dalam melakukan kegiatan pasti memerlukan adanya faktor logistik, salah satu faktor ini menyebabkan aktivitas pelaksanaan pelelangan berjalan dengan baik. Karena adanya dukungan fasilitas yang lengkap seperti tempat beribadah dan lahan parkir yang luas disediakan Tempat Pelelangan Ikan Pelabuhan Perikanan Nusantara Pekalongan.

b. Kegiatan Administrasi yang Tertib, Rapih, dan Aman

Kegiatan yang terorganisir maka wajib adanya proses administratif. Di Tempat Pelelangan Ikan PPN Pekalongan antara juru tulis buku nelayan dengan juru tulis buku bakul atau antara kasir terima untuk nelayan (penjual) dan kasir bayar untuk bakul (pembeli) bertugas sesuai dengan tugasnya masing-masing. Sehingga proses administrasi keuangan TPI berjalan dengan tertib, rapih, dan aman.

c. Faktor Cuaca (musim)

Sebelum melakukan kegiatan pencarian ikan haruslah memperhatikan faktor cuaca yang akan mempengaruhi banyak atau sedikitnya tangkapan ikan yang diperoleh. Dengan melihat juga musim ikan yang baik antara bulan Oktober-November, dan musim ikan yang rendah terjadi antara bulan Januari-Februari.

d. Banyaknya Juragan Kapal

Di Pelabuhan Perikanan Nusantara Pekalongan banyak diuntungkan dengan adanya banyak juragan kapal sehingga lebih banyak kapal yang melakukan kegiatan mencari ikan. Dan dapat mempengaruhi jumlah daftar nomor urut kapal yang masuk ke 
Pelabuhan Perikanan Nusantara Pekalongan untuk melakukan kegiatan pelelangan ikan.

\section{KESIMPULAN}

Kesimpulan yang dapat diambil dari penjelasan sebelumnya adalah sebagai berikut:

1. Praktik jual beli lelang ikan di TPI (Tempat Pelelangan Ikan) Pelabuhan Perikanan Nusantara Pekalongan, sedikit berbeda dengan praktek jual beli lelang ikan pada umumnya. Bahwa jual beli lelang ikan ini sangat rentan dengan spekulasi karena berat ikan perbasket ditentukan oleh juru tawar sehingga adanya ketidakakuratan juru tawar menentukan berat perbasket ikan, dan terkadang kondisi ikan (ngiyom) yang tidak sesuai dengan harga dan lain sebagainya. maka akibatnya dapat terjadi saling menyalahkan, ataupun merasa dirugikan antara pihak penjual (nelayan) maupun pembeli (bakul). Sementara itu jual beli ikan di TPI (Tempat Pelelangan Ikan) Pekalongan pihak antara penjual (nelayan) dan pembeli (bakul) sama-sama hadir dalam satu majlis/tempat meskipun pihak pemilik kapal selaku penjual tidak langsung menanganinya tetapi dengan memberikan kepercayaan kepada ABK (Anak Buah Kapal) yang sudah di tunjuk pemilik kapal (pemilik ikan) untuk mewakilinya dalam pelaksanaan pelelangan dengan persetujuan kedua belah pihak.

2. Hukum Islam memberikan ketentuan kebebasan dalam melakukan jual beli. Jual beli dengan sistem mewakili orang lain yang terjadi di TPI (Tempat Pelelangan Ikan) Pelabuhan

Jurnal IQTISAD - Volume 5, Nomor 1, Juni 2018

ISSN: 2303-3223 
Perikanan Nusantara Pekalongan dilakukan pemilik kapal selaku penjual dengan memberikan kepercayaan kepada ABK (Anak Buah Kapal) yang sudah di tunjuk pemilik kapal (pemilik ikan) dalam jual beli Islam dianggap sah selama terjadi adanya persetujuan antara keduanya dan dalam fiqh Islam disebut bai' alfudhuli.

3. Dalam melaksanakan semua kegiatan pasti terdapat faktor pendukung dan faktor penghambat dalam jual beli lelang ikan ini faktor pendukungnya yaitu sumber fasilitas yang baik dan lengkap di TPI, kegiatan administrasi yang tertib, rapih dan aman, faktor cuaca (musim) di daerah Pekalongan yang kaya akan potensi ikan, dan banyaknya juragan kapal. Kemudian faktor penghambatnya adalah perijinan kapal sulit, muara sungai dangkal, faktor cuaca (musim), dan sering terjadinya ketidakpuasan pembeli (bakul) sehingga terjadi saling menyalahkan ataupun merasa dirugikan antara pihak penjual (nelayan) maupun pembeli (bakul).

Jurnal IQTISAD - Volume 5, Nomor 1, Juni 2018

ISSN: 2303-3223 


\section{DAFTAR PUSTAKA}

Abdul Rozak, Kepala Urusan Administrasi, wawancara, tanggal 1 November 2016, jam 10:00-10:25 WIB, Tempat Pelelangan Ikan Pelabuhan Perikanan Nusantara Pekalongan.

Hadi, Sutrisno, Metode Research, Yogyakarta: Fakultas Psikologi UGM, 1983.

Haroen, Nasrun, MA. Fiqh Muamalah, Jakarta: Gaya Media Pratama, 2007.

Ibnu Hajar al-Asqalani, Bulughul Maram dan Dalil-dalil Hukum: Bab Syarat-syarat Jual Beli dan Hal-hal yang Tidak Boleh Diperjualbelikan, Hadits No. 816. Jakarta: Gema Insani, 2013.

Peraturan Daerah Kota Pekalongan Nomor 11 Tahun 2015 Tentang Pengelolaan Tempat Pelelangan Ikan, pasal 1, ayat 13.

Suhendi, Hendi, Fiqh Muamalat, cet. ke-6, Jakarta : Rajawali Pers, 2010

Jurnal IQTISAD - Volume 5, Nomor 1, Juni 2018

ISSN: 2303-3223 